\title{
Tinjauan Kemampuan Keterampilan Teknik Dasar Bola Voli Pada Siswa Ekstrakurikuler Bola Voli SMAN 1 Bunut
}

\author{
Rola Angga Lardika ${ }^{1}$, Salam $^{2}$ \\ Pendidikan Jasmani Kesehatan dan Rekreasi Universitas Riau ${ }^{1,2}$ \\ Email : rolaanggalardika@lecturer.unri.ac.id
}

\begin{abstract}
Abstrak
Tujuan penelitian ini adalah untuk mengungkapkan tentang tinjauan kemampuan keterampilan teknik dasar bola voli pada siswa ekstrakurikuler bola voli SMAN 1 Bunut. Penelitian ini tergolong pada penelitian deskripitif. Penelitian ini menggunakan teknik total sampling (sampel jenuh), dimana seluruh populasi yang dijadikan sebagai sampel. Berdasarkan penentuan sampel di atas maka didapat sampel sebanyak 20 siswa yang mengikuti ekstrakurikuler Bola Voli SMAN 1 Bunut. Berdasarkan hasil penelitian yang telah diuraikan pada bab terdahulu dapat dikemukakan kesimpulan bahwa: Tingkat kemampuan passing bawah yang dominan dimiliki siswa ekstrakurikuler Bolavoli di Sekolah SMAN 1 Bunut Kabupaten Pelalawan adalah 1,7-80,5 tergolong baik. (36,36\%), Tingkat kemampuan passing atas yang dominan dimiliki siswa ekstrakurikuler Bolavoli di Sekolah SMAN 1 Bunut Kabupaten Pelalawan adalah 48,7-56,5 tergolong kategori baik (40,90\%), Tingkat kemampuan servis yang dominan dimiliki siswa ekstrakurikuler Bolavoli di Sekolah SMAN 1 Bunut Kabupaten Pelalawan adalah 13,3-1452 tergolong kategori kurang (31,80\%), Tingkat kemampuan smash yang dominan dimiliki siswa ekstrakurikuler Bolavoli di Sekolah SMAN 1 Bunut Kabupaten Pelalawan adalah 13,9-15,7 tergolong kategori kurang $(36,36 \%)$.
\end{abstract}

Kata kunci: Keterampilan dasar Bola Voli, Ekstrakurikuler

\section{Descriptive of Volleyball Basic Skills on Volleyball Extracurricular Students SMAN 1 Bunut}

\begin{abstract}
The purpose of this study was to reveal a review of the ability of volleyball basic technical skills in volleyball extracurricular students at SMAN 1 Bunut. This research belongs to descriptive research. This study uses a total sampling technique (saturated sample), in which the entire population is sampled. Based on the determination of the sample above, 20 samples were obtained from students who joined the Volleyball extracurricular at SMAN 1 Bunut. Based on the results of the research described in the previous chapter, it can be concluded that: The dominant level of under-passing ability possessed by Bolavoli extracurricular students at SMAN 1 Bunut School in Pelalawan Regency is 1.7-80.5, which is classified as good. (36.36\%), the level of passing ability over the dominant extracurricular students possessed at Bolavoli SMAN 1 Bunut Pelalawan Regency was 48.7-56.5 classified as good category (40.90\%), the level of service ability dominantly possessed by extracurricular students The volleyball at SMAN 1 Bunut in Pelalawan Regency is 13.3-1452 classified as less (31.80\%), the dominant level of smash ability possessed by extracurricular students Bolavoli at SMAN 1 Bunut Pelalawan Regency is 13.9-15.7 classified as a category less (36.36\%).
\end{abstract}

Keywords: Volleyball Basic skills, extracurricular 


\section{PENDAHULUAN}

Physical education is a strategic way in building a nation because the activity and characteristics contain social and intellectual proficiency (Lardika, 2014: i).

Olahraga merupakan sebuah sarana bagaimana individu maupun kelompok dapat mengaktualisasikan diri dengan tujuan membangkitkan rasa kepercayaan diri dan kebanggan nasionalnya. Peningkatan prestasi olahraga bagi bangsa dan negara merupakan alasan yang tepat untuk meningkatkan pembangunan di bidang olahrag. Melalui prestasi olahraga, negara-negara di dunia akan dapat mengetahui bahwa bangsa Indonesia sebagai negara yang berkembang juga mampu berprestasi seperti negara-negara berkembang lainnya. Tujuan dari pembinaan dan pengembangan olahraga di Indonesia adalah untuk meningkatkan prestasi, maka untuk dapat mengejar prestasi puncak hendaknya ditempuh melalui pendekatan secara ilmiah (Satya, 2006: 12).

Olahraga memiliki manfaat yang sangat banyak, seperti manfaat dalam aspek fisik, manfaat dalam aspek sosial, manfaat dalam aspek ekonomi, maupun aspek dalam ketenangan rohani (Arsil, 2000: 87). Dalam aspek fisik seorang pelaku olahraga secara langsung akan berdampak pada derajat sehat statis dan dinamisnya. Dengan melaksanakan olahraga juga seseoranga akan memiliki jiwa social seperti kerjasama, sportif, saling menghargai, dll. Olahraga yang banyak dimainkan oleh sebagian masyarakat Indonesia adalan olahraga Bolavoli.

Bola voli merupakan sebuah cabang olahraga yang sangat digemari oleh masyarakat luas. Peak-performance volleyball is characterised by teams' search for equilibrium between the different actions, complexes, or game phases (Valao, J.M. and Valades, D, 2019: 1). Pembinaan dan pengembangan olahraga khususnya olahraga bolavoli sudah menjadi tanggung jawab bersama mulai dari pusat sampai daerah. Melalui induk organisasi yang ada di pusat dan daerah maka diharapkan adanya pembinaan yang baik. Berbicara masalah pengembangan olahraga prestasi Siswa Ekstrakurikuler Bola Voli SMAN 1 Bunutikut andil dalam mengembangkan prestasi olahraga bolavoli. Hal ini terlihat dalam upaya peningkatan prestasi bolavoli yang ada di sekolah-sekolah di Bunut. Salah satu upaya yang pernah dilakukan adalah peningkatan teknik dasar pemain Bolavoli siswa ekstrakurikuler bola voli SMAN 1 Bunut, dimana teknik dasar merupakan faktor penting dan berpengaruh serta dibutuhkan dalam permainan bolavoli. Penguasaan teknik dasar yang baik merupakan suatu prasyarat yang harus dimiliki oleh setiap pemain Bolavoli siswa ekstrakurikuler bola voli SMAN 1 Bunut. Dimana hal ini sangat menentukan sampai dimana seorang pemain Bolavoli siswa ekstrakurikuler bola voli SMAN 1 Bunut dapat meningkatkan mutu permainannya. Selain itu, penguasaan teknik dasar yang baik dan sempurna, pemain dapat melaksanakan taktik permainan dengan 
mudah karena pemain tersebut mempunyai kepercayaan pada diri sendiri cukup tinggi dan setiap keterampilan yang dilakukan tidak banyak membuang tenaga yang tidak perlu. (Syafruddin, 2005: 129) menyatakan bahwa:"Penguasaan terhadap suatu teknik menyebutnya dengan keterampilan teknik, di samping itu penguasaan teknik yang baik akan dapat menghemat penggunaan tenaga. Ini berarti bahwa semakin baik teknik yang dimiliki semakin efisien kita menggunakan tenaga yang dibutuhkan".

Dari urain di atas, untuk meningkatkan prestasi permainan bolavoli ada 4 komponen yang harus mendapatkan perhatian yaitu ; kondisi fisik, teknik, taktik dan mental. Komponen yang dibutuhkan dalam olahraga secara umum, yaitu kecepatan, kekuatan, kelincahan, daya tahan, power, koordinasi, kelentukan, endurance (Bompa, 1990: 52). Hal ini sesuai dengan yang dikemukakan (Sajoto, 1995: 23) yaitu: "prestasi olahraga dipengaruhi dan ditentukan oleh kemampuan atlet itu sendiri secara menyeluruh baik menyangkut kemampuan fisiknya, teknik, taktik maupun oleh kemampuan mental (psikis) nya". Oleh karena itu untuk memenuhi hal tersebut atlet harus memiliki empat komponen prestasi yang baik, terutama kemampuan teknik.

Namun sangat disayangkan, siswa ekstrakurikuler bola voli SMAN 1 Bunut tidak banyak memiliki pemain bolavoli yang dapat diandalkan, hal ini terbukti dari hasil setiap turnamen, belum pernah mendapatkan prestasi puncak.Artinya, Tim olahraga tertentu merupakan gambaran tingkat keterampilan yang dimiliki terhadap teknik tersebut, semakin baik teknik seseorang semakin tinggi tingkat keterampilan yang dimilikinya. Oleh karena itu para ahli cenderung bolavoli siswa ekstrakurikuler bola voli SMAN 1 Bunut belum berhasil memperoleh prestasi maksimal. Banyak faktor yang menyebabkan kegagalan dalam pencapaian prestasi maksimal, salah satunya program latihan teknik yang diterapkan kurang tepat. Perolehan angka di dalam permainan bolavoli diperoleh dari hasil kerjasama pemain dalam usaha mematikan bola di daerah lawan dan tim yang melakukan berbagai gerakan keterampilan seperti; passing atas, passing bawah, dan smash merupakan pondasi atau dasar bagi seseorang untuk dapat bermain bolavoli dengan baik.

Teknik mempunyai fungsi penting dalam bermain bolavoli. Untuk dapat menghasilkan kemampuan bermain yang baik, dibutuhkan suatu keterampilan yang baik dari seorang pemain bolavoli. Bolavoli di siswa ekstrakurikuler bola voli SMAN 1 Bunutcukup representatif, memiliki lapangan yang bagus serta pelatih yang professional. Namun sangat disayangkan prestasi yang dihasilkan belum memuaskan meskipun sudah melakukan pelatihan dan pembinaan. Berdasarkan pemantauan peneliti dari fenomena yang terjadi di lapangan peneliti menduga kemampuan bermain pemain bolavoli siswa ekstrakurikuler bola voli SMAN 1 Bunutmasih jauh dari yang diharapkan hal 
ini terbukti dari menurunnya penampilan atlet dalam melakukan keterampilan seperti saat melakukan passing bawah, passing atas, servis, dan smash. Servis yang dilakukan sering gagal, passing bawah yang dilakukan selalu tidak tepat pada arah tujuan yang diinginkan, pemberian bola dari passing atas untuk pelaksanaan smash terlalu tinggi atau terlalu rendah sehingga pemain kesulitan dalam memperoleh poin.

Jika hal ini dibiarkan maka prestasi maksimal yang diharapkan akan sulit untuk

\section{METODE PENELITIAN}

Penelitian ini tergolong pada penelitian deskripitif, dimana penelitian ini dilakukan untuk melihat teknik bermain bolavoli pada siswa ekstrakurikuler bola voli SMAN 1 Bunut. (Sudjana, 1986: 64) mengemukakan "Penelitian deskriptif adalah penelitian yang berusaha mendeskriptifkan suatu gejala dan kejadian dimasa sekarang atau untuk meneliti masalah-masalah aktual sebagaimana adanya pada saat penelitian dilakukan". Penelitian ini menggunakan teknik total sampling (sampel jenuh), dimana seluruh populasi yang dijadikan sebagai sampel. Sampel merupakan bagian/keseluruhan populasi yang dijadikan sumber data (Arikunto, 2006: 112). Berdasarkan penentuan sampel di atas maka didapat sampel sebanyak 20 orang. Tes dan diraih, untuk itu peneliti tertarik melakukan penelitian dengan judul "tinjauan kemampuan bermain Bolavoli Atlet Bolavoli di siswa ekstrakurikuler bola voli SMAN 1 Bunut". Sehingga dari hasil penelitian ini bisa dilahirkan suatu kesimpulan yang bisa dijadikan langkah antisipatif bagi peningkatan prestasi perbolavolian di SMAN 1 Bunutsecara khusus dan Kabupaten Pelalawan secara umumnya.

Instrumen teknik dasar bola voli ada 3, yaitu Passing, Smash, Servis (Nurhasan, 2001: 114). Setelah diperoleh data dari instrument, maka akan diolah menggunakan rumus $\mathrm{P}=\mathrm{f} / \mathrm{n}$ x 100 (Ritonga, 2007: 87).

\section{HASIL DAN PEMBAHASAN}

Analisis data penelitian dilakukan secara berurutan sesuai dengan urutan pada pertanyaan dan tujuan penelitian. Semua data dianalisis secara statistik deskriptif dengan tabulasi frekuensi. Adapun variabelvariabel yang diteliti tersebut adalah sebagai berikut:

\section{Passing Bawah}

Kemampuan passing bawah diukur dengan menggunakan tes keterampilan passing bawah. Hasil tes tersebut dapat dilihat pada tabel berikut :

Tabel 1. Hasil Tes passing bawah Atlet Bolavoli di Sekolah SMAN 1 Bunut Kabupaten Pelalawan

\begin{tabular}{ccccc}
\hline No & Nama & Usia & Passing Bawah & Klasifikasi \\
\hline 1 & Pratama & 16 & 70 & B \\
\hline 2 & Angga & 16 & 74 & BS \\
\hline
\end{tabular}




\begin{tabular}{|c|c|c|c|c|}
\hline 3 & Wiji & 17 & 70 & B \\
\hline 4 & Ari & 17 & 69 & B \\
\hline 5 & Putra & 17 & 74 & B \\
\hline 6 & Adnan & 17 & 60 & K \\
\hline 7 & Reski & 16 & 79 & BS \\
\hline 8 & Risqi & 16 & 70 & $\mathrm{C}$ \\
\hline 9 & Fajar & 16 & 55 & K \\
\hline 10 & Rahmad & 16 & 65 & $\mathrm{C}$ \\
\hline 11 & Hendra & 16 & 70 & $\mathrm{C}$ \\
\hline 12 & Adi & 16 & 70 & B \\
\hline 13 & Helmi & 17 & 78 & BS \\
\hline 14 & Trisandi & 16 & 45 & KS \\
\hline 15 & Sulaiman & 17 & 72 & B \\
\hline 16 & Wawan & 16 & 45 & KS \\
\hline 17 & Tio & 17 & 73 & BS \\
\hline 18 & Heru & 16 & 75 & B \\
\hline 19 & Badri & 16 & 75 & BS \\
\hline 20 & Chandra & 17 & 60 & K \\
\hline
\end{tabular}

Sumber: Data Olahan Tahun 2019

Berdasarkan tabel hasil tes passing bawah

Atlet Bolavoli di Sekolah SMAN 1 Bunut
Kabupaten Pelalawan dapat diperoleh data distribusi frekuensi sebagai berikut:

Tabel 2. Distribusi Frekuensi passing bawah Atlet Bolavoli di Sekolah SMAN 1 Bunut Kabupaten Pelalawan

\begin{tabular}{|c|c|c|c|}
\hline \multirow{2}{*}{ No } & \multirow{2}{*}{ Kelas Interval } & \multicolumn{2}{|c|}{ Frekuensi } \\
\hline & & Absolut (Fa) & Relatif (\%) \\
\hline 1 & $70.6-79.4$ & 5 & 20,72 \\
\hline 2 & $61.7-70.5$ & 8 & 36,36 \\
\hline 3 & $52.8-61.6$ & 4 & 18,18 \\
\hline 4 & $43.9-52.7$ & 3 & 13,60 \\
\hline \multirow[t]{2}{*}{5} & $35-43.8$ & 2 & 9,09 \\
\hline & Jumlah & 20 & 100 \\
\hline \multicolumn{2}{|r|}{ Rata-rata } & \multicolumn{2}{|c|}{62.13} \\
\hline \multicolumn{2}{|r|}{ Skor Maxsimum } & \multicolumn{2}{|c|}{79} \\
\hline & Skor Minimum & \multicolumn{2}{|c|}{45} \\
\hline
\end{tabular}

Sumber: Data Olahan 2019 
Berdasarkan tabel di atas diperoleh hasil tes passing bawah atlet bolavoli di Sekolah SMAN 1 Bunut Kabupaten Pelalawan melalui tes keterampilan passing bawah. Dari tes diperoleh skor maksimum 79 tergolong kategori baik sekali dan skor minimum 35 tergolong kategori kurang sekali. Rata - rata tingkat passing bawah atlet bolavoli di Sekolah SMAN 1 Bunut Kabupaten Pelalawan $=72.13$ tergolong kategori baik.

\section{Passing Atas}

Kemampuan passing atas di ukur melalui tes keterampilan passing atas. Hasil tes tersebut dapat dilihat sebagai berikut :

Tabel 3. Hasil Tes passing atas Atlet Bolavoli di Sekolah SMAN 1 Bunut Kabupaten Pelalawan

\begin{tabular}{|c|c|c|c|c|}
\hline No & Nama & Usia & Passing atas & Klasifikasi \\
\hline 1 & Pratama & 16 & 32 & $\mathrm{KS}$ \\
\hline 2 & Angga & 16 & 35 & $\mathrm{~K}$ \\
\hline 3 & Wiji & 17 & 46 & $\mathrm{C}$ \\
\hline 4 & Ari & 17 & 50 & B \\
\hline 5 & Putra & 17 & 49 & B \\
\hline 6 & Adnan & 17 & 50 & B \\
\hline 7 & Reski & 16 & 49 & B \\
\hline 8 & Risqi & 16 & 50 & $\mathrm{~B}$ \\
\hline 9 & Fajar & 16 & 36 & $\mathrm{~K}$ \\
\hline 10 & Rahmad & 16 & 47 & $\mathrm{C}$ \\
\hline 11 & Hendra & 16 & 56 & $\mathrm{~B}$ \\
\hline 12 & Adi & 16 & 58 & $\mathrm{BS}$ \\
\hline 13 & Helmi & 17 & 61 & BS \\
\hline 14 & Trisandi & 16 & 64 & BS \\
\hline 15 & Sulaiman & 17 & 55 & $\mathrm{~B}$ \\
\hline 16 & Wawan & 16 & 49 & $\mathrm{~B}$ \\
\hline 17 & Tio & 17 & 35 & $\mathrm{~K}$ \\
\hline 18 & Heru & 16 & 31 & $\mathrm{KS}$ \\
\hline 19 & Badri & 16 & 25 & $\mathrm{KS}$ \\
\hline 20 & Chandra & 17 & 25 & KS \\
\hline
\end{tabular}

Sumber: Data Olahan 2019

Berdasarkan tabel hasil tes tes passing atas atlet bolavoli di Sekolah SMAN 1 Bunut
Kabupaten Pelalawan dapat diperoleh data distribusi sebagai berikut :

Tabel 4. Distribusi Frekuensi passing atas Atlet Bolavoli di Sekolah SMAN 1 Bunut Kabupaten Pelalawan

\begin{tabular}{cccc}
\hline \multirow{2}{*}{ No } & \multirow{2}{*}{ Kelas Interval } & \multicolumn{2}{c}{ Frekuensi } \\
\cline { 3 - 4 } & & Absolut (Fa) & Relatif $(\%)$ \\
\hline 1 & $56.6-64.4$ & 3 & 13,60 \\
\hline 2 & $48.7-56.5$ & 9 & 40,90 \\
\hline
\end{tabular}




\begin{tabular}{cccc}
\hline 3 & $40.8-48.6$ & 2 & 9,09 \\
\hline 4 & $32.9-40.7$ & 3 & 13,60 \\
\hline 5 & $25-32.8$ & 5 & 20,72 \\
\hline Jumlah & 20 & & 100 \\
\hline Rata-rata & & 44.63 & \\
\hline $\begin{array}{c}\text { Skor } \\
\text { Maksimum }\end{array}$ & 64 & \\
\hline $\begin{array}{c}\text { Skor } \\
\text { Minimum }\end{array}$ & & 25 & \\
\hline
\end{tabular}

Sumber: Data Olahan 2019

Berdasarkan tabel di atas diperoleh hasil tes passing atas atlet bolavoli di Sekolah SMAN 1 Bunut Kabupaten Pelalawan melalui tes keterampilan passing atas. Dari tes diperoleh skor maksimum 64 tergolong kategori Baik sekali dan skor minimum 25 tergolong kategori kurang sekali. Rata rata tingkat passing atas atlet Bolavoli di
Sekolah SMAN 1 Bunut Kabupaten

Pelalawan $=44,63$ tergolong kategori

Cukup.

\section{Servis}

Kemampuan servis di ukur melalui tes keterampilan servis. Hasil tes tersebut dapat dilihat sebagai berikut :

Tabel 5. Hasil Tes Servis Atlet Bolavoli di Sekolah SMAN 1 Bunut Kabupaten Pelalawan

\begin{tabular}{ccccc}
\hline No & Nama & Usia & Servis & Klasifikasi \\
\hline 1 & Pratama & 16 & 14 & $\mathrm{~K}$ \\
\hline 2 & Angga & 16 & 14 & $\mathrm{~K}$ \\
\hline 3 & Wiji & 17 & 17 & $\mathrm{~B}$ \\
\hline 4 & Ari & 17 & 14 & $\mathrm{~K}$ \\
\hline 5 & Putra & 17 & 12 & KS \\
\hline 6 & Adnan & 17 & 15 & $\mathrm{C}$ \\
\hline 7 & Reski & 16 & 17 & $\mathrm{~B}$ \\
\hline 8 & Risqi & 16 & 18 & $\mathrm{BS}$ \\
\hline 9 & Fajar & 16 & 12 & $\mathrm{KS}$ \\
\hline 10 & Rahmad & 16 & 12 & $\mathrm{KS}$ \\
\hline 11 & Hendra & 16 & 14 & $\mathrm{C}$ \\
\hline 12 & Adi & 16 & 15 & $\mathrm{C}$ \\
\hline 13 & Helmi & 17 & 15 & $\mathrm{~K}$ \\
\hline 14 & Trisandi & 16 & 14 & $\mathrm{BS}$ \\
\hline 15 & Sulaiman & 17 & 18 & $\mathrm{~B}$ \\
\hline 16 & Wawan & 16 & 17 & $\mathrm{~K}$ \\
\hline 17 & Tio & 17 & 14 & $\mathrm{~K}$ \\
\hline 18 & Heru & 16 & 14 & $\mathrm{C}$ \\
\hline 19 & Badri & 16 & 15 & KS \\
\hline 20 & Chandra & 17 & 12 & \\
\hline
\end{tabular}

Sumber: Data Olahan 2019 
Berdasarkan tabel hasil tes tes servis atlet

Bolavoli di Sekolah SMAN 1 Bunut
Kabupaten Pelalawan dapat diperoleh data distribusi sebagai berikut:

Tabel 6. Distribusi Frekuensi Servis Atlet Bolavoli di Sekolah

SMAN 1 Bunut Kabupaten Pelalawan

\begin{tabular}{cccc}
\hline \multirow{2}{*}{ No } & \multirow{2}{*}{ Kelas Interval } & Absolut $(\mathrm{Fa})$ & Frekuensi \\
\cline { 2 - 4 } & $17,2-18,4$ & 2 & Relatif $(\%)$ \\
\hline 1 & $15,9-17,1$ & 3 & 9,09 \\
\hline 2 & $14,6-15,8$ & 4 & 13,60 \\
\hline 3 & $13,3-14,5$ & 7 & 18,18 \\
\hline 4 & $12-13,2$ & 6 & 31,80 \\
\hline 5 & Jumlah & 20 & 100 \\
\hline & Rata-rata & 14,5 & \\
\hline & Skor Maxsimum & 18 \\
\hline & Skor Minimum & 12 \\
\hline
\end{tabular}

Sumber: Data Olahan 2019

Berdasarkan tabel di atas diperoleh hasil tes servis atlet Bolavoli di Sekolah SMAN 1

Bunut Kabupaten Pelalawan melalui tes keterampilan servis. Dari tes diperoleh skor maksimum 18 tergolong kategori baik sekali dan skor minimum 12 tergolong kategori kurang sekali. Rata - rata tingkat servis atlet Bolavoli di Sekolah SMAN 1
Bunut Kabupaten Pelalawan 14,5 tergolong kategori kurang. Agar lebih jelasnya hasil servis dapat dilihat pada gambar histogram sebagai berikut :

\section{Smash}

Kemampuan smash di ukur melalui tes keterampilan smash. Hasil tes tersebut dapat dilihat sebagai berikut :

Tabel 7. Hasil Tes Smash Atlet Bolavoli di Sekolah SMAN 1 Bunut Kabupaten Pelalawan

\begin{tabular}{ccccc}
\hline No & Nama & Usia & Smash & Klasifikasi \\
\hline 1 & Pratama & 16 & 12 & KS \\
\hline 2 & Angga & 16 & 14 & $\mathrm{~K}$ \\
\hline 3 & Wiji & 17 & 14 & $\mathrm{~K}$ \\
\hline 4 & Ari & 17 & 16 & $\mathrm{C}$ \\
\hline 5 & Putra & 17 & 17 & $\mathrm{C}$ \\
\hline 6 & Adnan & 17 & 12 & $\mathrm{KS}$ \\
\hline 7 & Reski & 16 & 15 & $\mathrm{~K}$ \\
\hline 8 & Risqi & 16 & 21 & $\mathrm{BS}$ \\
\hline 9 & Fajar & 16 & 12 & $\mathrm{KS}$ \\
\hline 10 & Rahmad & 16 & 13 & $\mathrm{~K}$ \\
\hline 11 & Hendra & 16 & 14 & $\mathrm{~K}$ \\
\hline 12 & Adi & 16 & 14 & $\mathrm{C}$ \\
\hline 13 & Helmi & 17 & 17 & $\mathrm{C}$ \\
\hline 14 & Trisandi & 16 & 17 & $\mathrm{~K}$ \\
\hline 15 & Sulaiman & 17 & 15 & $\mathrm{KS}$ \\
\hline 16 & Wawan & 16 & 12 & $\mathrm{C}$ \\
\hline 17 & Tio & 17 & 14 & \\
\hline 18 & Heru & 16 & 16 & \\
\hline
\end{tabular}




\begin{tabular}{lcccc}
\hline 19 & Badri & 16 & 17 & $\mathrm{C}$ \\
\hline 20 & Chandra & 17 & 16 & $\mathrm{C}$ \\
\hline
\end{tabular}

Sumber: Data Olahan 2019

Berdasarkan tabel hasil tes tes smash atlet

Bolavoli di Sekolah SMAN 1 Bunut
Kabupaten Pelalawan dapat diperoleh data distribusi sebagai berikut :

Tabel 8. Distribusi Frekuensi Smash Atlet Bolavoli di Sekolah

SMAN 1 Bunut Kabupaten Pelalawan

\begin{tabular}{cccc}
\hline \multirow{2}{*}{ No } & \multirow{2}{*}{ Kelas Interval } & \multicolumn{3}{c}{ Frekuensi } \\
\cline { 2 - 4 } & & Absolut $(\mathrm{Fa})$ & Relatif $(\boldsymbol{\%})$ \\
\hline 1 & $19,6-21,4$ & 1 & 4,5 \\
\hline 2 & $17,7-19,5$ & 0 & 0,00 \\
\hline 3 & $15,8-17,6$ & 7 & 31,80 \\
\hline 4 & $13,9-15,7$ & 8 & 36,36 \\
\hline 5 & $12-13,8$ & 6 & $\mathbf{1 0 0}$ \\
\hline & Jumlah & 20 & 14,77 \\
\hline & Rata-rata & 21 \\
\hline & Skor Maxsimum & 12 \\
\hline & Skor Minimum
\end{tabular}

Sumber: Data Olahan 2019

Berdasarkan tabel di atas diperoleh hasil tes smash atlet Bolavoli di Sekolah SMAN 1

Bunut Kabupaten Pelalawan melalui tes keterampilan smash. Dari tes diperoleh skor maksimum 21 tergolong kategori baik sekali dan skor minimum 12 tergolong kategori kurang sekali. Rata - rata tingkat smash atlet Bolavoli di Sekolah SMAN 1
Bunut Kabupaten Pelalawan $=14,77$ tergolong kategori kurang.

Berdasarkan analisis data penelitian mengenai kemampuan bermain bolavoli atlet bolavoli di Sekolah SMAN 1 Bunut Kabupaten Pelalawan dari kemampuan passing bawah, passing atas, servis dan smash. Agar lebih jelasnya dapat dilihat pada tabel sebagai berikut:

Tabel 9. Kategori Standar Penilaian Kemampuan Bermain Bolavoli

\begin{tabular}{|c|c|c|c|c|}
\hline \multirow{2}{*}{ No } & \multirow{2}{*}{ Kelas Interval } & \multicolumn{2}{|c|}{ Frekuensi } & \multirow{2}{*}{ Kategori Penilaian } \\
\hline & & Absolut (Fa) & Relatif(\%) & \\
\hline 1 & $167.8-181.4$ & 2 & 9.09 & $>19$ \\
\hline 2 & $154.1-167.7$ & 6 & 27.27 & $15-19$ \\
\hline 3 & $140.4-154.0$ & 5 & 20.72 & $10-14$ \\
\hline 4 & $126.7-140.3$ & 5 & 20.72 & $5-9$ \\
\hline 5 & $113-126.6$ & 4 & 18.18 & $<9$ \\
\hline \multicolumn{2}{|r|}{ Jumlah } & 20 & 100 & - \\
\hline
\end{tabular}


Berdasarkan tabel di atas dari 20 orang atlet, 2 orang $(9,09 \%)$ memiliki kemampuan bermain bolavoli 167,8-181,4 dengan penilaian $>19$ tergolong kategori baik sekali, 6 orang $(27,27 \%)$ memiliki 154,1-167,7 dengan penilaian 15-19 tergolong kategori baik, 5 orang $(20,72 \%)$

\section{SIMPULAN}

Penelitian ini tergolong pada penelitian deskripitif, dimana penelitian ini dilakukan untuk melihat teknik bermain bolavoli pada siswa ekstrakurikuler bola voli SMAN 1 Bunut. Berdasarkan hasil penelitian yang telah diuraikan pada bab terdahulu dapat dikemukakan kesimpulan bahwa :

1. Tingkat kemampuan passing bawah yang dominan dimiliki siswa ekstrakurikuler Bolavoli di Sekolah SMAN 1 Bunut Kabupaten Pelalawan adalah 1,7-80,5 tergolong baik. $(36,36 \%)$.

2. Tingkat kemampuan passing atas yang dominan dimiliki siswa ekstrakurikuler Bolavoli di Sekolah SMAN 1 Bunut Kabupaten Pelalawan adalah 48,7-56,5 tergolong kategori baik $(40,90 \%)$.

3. Tingkat kemampuan servis yang dominan dimiliki siswa ekstrakurikuler Bolavoli di Sekolah SMAN 1 Bunut Kabupaten Pelalawan adalah 13,3-1452 tergolong kategori kurang $(31,80 \%)$.

4. Tingkat kemampuan smash yang dominan dimiliki siswa ekstrakurikuler Bolavoli di Sekolah SMAN 1 Bunut Kabupaten Pelalawan adalah 13,9-15,7 tergolong kategori kurang $(36,36 \%)$. memiliki 140,4-154,0 dengan penilaian 1014 tergolong kategori cukup, 5 orang $(20,72 \%)$ memiliki 126,7-140,3 dengan penilaian 5-9 tergolong kategori kurang dan 4 orang (18,18\%) memiliki 113-126,6 dengan penilaian $<9$ tergolong kategori kurang sekali.

\section{DAFTAR PUSTAKA}

Arikunto, S. 2006. Prosedur Penelitian Suatu Pendekatan Praktek. PT. Rineka Cipta. Jakarta.

Arsil, 2000. Pembinaan Kondisi Fisik. F.I.K UNP. Padang.

Bompa, T.O. 1990. Total Training for Young Champions. USA: New York University

Lardika, R.A. (2014). Pengaruh model pembelajaran inquiry dalam pendidikan jasmani terhadap tingkat adversity quotient (aq) siswa. Tesis pada Universitas Pendidikan Indonesia.

Nurhasan. 2001. Tes dan Pengukuran dalam Pendidikan Jasmani. Jakarta: Depdiknas

Sajoto,M. 1995. Peningkatan dan Pembinaan Kondisi Fisik dalam Olahraga. Dahara Prize. Semarang.

Satya, WI. 2006. Membangn Kebugaran Jasmani dan Kecerdasan Melalui Bermain. Jakarta: Depdiknas

Syafruddin, 1999. Teknik dan Taktik dalam Bolavoli. Padang: UNP Press.

Ritonga, Zulfan. 2007. Statistik Untuk IlmuIlmu Sosial. Pekanbaru: UNRI Press.

Valao, J.M. and Valades, D. 2019. Normative profiles for serve speed for the training of the serve and reception in volleyball.(https://thesportjourn al.org/), Vol 21. ISSN: 1543-951 